\title{
Analysis of genomic and non-genomic signaling of estrogen receptor in PDX models of breast cancer treated with a combination of the PI3K inhibitor alpelisib (BYL719) and fulvestrant
}

Julien Jacquemetton ${ }^{1,2,3}$, Loay Kassem ${ }^{4}$, Coralie Poulard ${ }^{1,2,3}$, Ahmed Dahmani $^{5}$, Ludmilla De Plater ${ }^{5}$, Elodie Montaudon ${ }^{5}$, Laura Sourd ${ }^{5}$, Ludivine Morisset ${ }^{5}$, Rania El Botty ${ }^{5}$, Sophie Chateau-Joubert ${ }^{6}$, Sophie Vacher ${ }^{7}$, Ivan Bièche ${ }^{7}$, Isabelle Treilleux ${ }^{1,2,3,8}$, Olivier Trédan ${ }^{1,2,3,9}$, Elisabetta Marangoni ${ }^{5+}$ and Muriel Le Romancer ${ }^{1,2,3,10^{*}+}$

\begin{abstract}
Background: Endocrine therapies targeting estrogen signaling have significantly improved breast cancer (BC) patient survival, although $40 \%$ of ERa-positive BCs do not respond to those therapies. Aside from genomic signaling, estrogen triggers non-genomic pathways by forming a complex containing methylERa/Src/PI3K, a hallmark of aggressiveness and resistance to tamoxifen. We aimed to confirm the prognostic value of this complex and investigated whether its targeting could improve tumor response in vivo.

Methods: The interaction of ERa/Src and ERa/PI3K was studied by proximity ligation assay (PLA) in a cohort of 440 $B C$ patients. We then treated patient-derived BC xenografts (PDXs) with fulvestrant or the PI3K inhibitor alpelisib (BYL719) alone or in combination. We analyzed their anti-proliferative effects on 6 ERa+ and 3 ERa- PDX models. Genomic and non-genomic estrogen signaling were assessed by measuring ERa/PI3K interaction by PLA and the expression of estrogen target genes by RT-QPCR, respectively.
\end{abstract}

\footnotetext{
* Correspondence: muriel.leromancer@lyon.unicancer.fr

${ }^{\dagger}$ Elisabetta Marangoni and Muriel Le Romancer contributed equally to this manuscript.

'Université de Lyon, F-69000 Lyon, France

${ }_{2}^{2}$ Inserm U1052, Centre de Recherche en Cancérologie de Lyon, F-69000 Lyon, France

Full list of author information is available at the end of the article
}

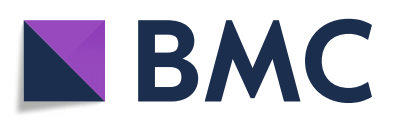

(- The Author(s). 2021 Open Access This article is licensed under a Creative Commons Attribution 4.0 International License, which permits use, sharing, adaptation, distribution and reproduction in any medium or format, as long as you give appropriate credit to the original author(s) and the source, provide a link to the Creative Commons licence, and indicate if changes were made. The images or other third party material in this article are included in the article's Creative Commons licence, unless indicated otherwise in a credit line to the material. If material is not included in the article's Creative Commons licence and your intended use is not permitted by statutory regulation or exceeds the permitted use, you will need to obtain permission directly from the copyright holder. To view a copy of this licence, visit http://creativecommons.org/licenses/by/4.0/. The Creative Commons Public Domain Dedication waiver (http://creativecommons.org/publicdomain/zero/1.0/) applies to the data made available in this article, unless otherwise stated in a credit line to the data. 
(Continued from previous page)

Results: We confirmed that ERa/Src and ERa/PI3K interactions were associated with a trend to poorer survival, the latter displaying the most significant effects. In ERa+tumors, the combination of BYL719 and fulvestrant was more effective than fulvestrant alone in 3 models, irrespective of PI3K, PTEN status, or ERa/PI3K targeting. Remarkably, resistance to fulvestrant was associated with non-genomic ERa signaling, since genomic degradation of ERa was unaltered in these tumors, whereas the treatment did not diminish the level of ERa/PI3K interaction. Interestingly, in $2 \mathrm{ERa}$ - models, fulvestrant alone impacted tumor growth, and this was associated with a decrease in ERa/PI3K interaction.

Conclusions: Our results demonstrate that ERa/PI3K may constitute a new prognostic marker, as well as a new target in BC. Indeed, resistance to fulvestrant in ERa+ tumors was associated with a lack of impairment of ERa/PI3K interaction in the cytoplasm. In addition, an efficient targeting of ERa/PI3K in ERa- tumors could constitute a promising therapeutic option.

Keywords: Breast cancer, Estrogen signaling, Resistance, PI3K, PDX, Biomarker

\section{Background}

Breast cancer $(\mathrm{BC})$ is the most common cancer among women worldwide [1]. More than $75 \%$ of breast tumors express the estrogen receptor $\alpha$ (ER $\alpha$ in the nucleus and are commonly categorized as luminal BCs). ER $\alpha$ plays a major role in $\mathrm{BC}$ tumorigenesis as it regulates cell cycle, cell survival, and angiogenesis [2]. Interfering with the ER $\alpha$ pathway using anti-estrogens (selective estrogen receptor modulators such as tamoxifen or selective estrogen downregulators such as fulvestrant) or through estrogen deprivation (e.g., aromatase inhibitors) increases the survival of ER $\alpha$-positive BC patients. Despite the high level of sensitivity of luminal tumors to endocrine therapy, treatment efficacy is limited by intrinsic and acquired resistance [3, 4]. Indeed, 30-50\% of patients relapse after adjuvant treatment and eventually die from metastases [5].

The PIK3CA gene, encoding the $\mathrm{p} 110 \alpha$ subunit of $\mathrm{PI} 3 \mathrm{~K}$, is mutated in $40-50 \%$ of $\mathrm{ER} \alpha+$ tumors, suggesting a dependency of ER $\alpha+$ breast cancer cells on this pathway [6, 7]. Given the role of PI3K in supporting proliferation, survival, and hormone receptor pathway activity, it is not surprising that activation of the PI3K/AKT/ mTOR pathway promotes disease progression and resistance to endocrine therapy [8]. PIK3CA-mutated preclinical cancer models are sensitive to PI3K inhibitors, which appear to function synergistically with endocrine therapies [9]. This was recently confirmed in patients, as treatment with alpelisib (PI3K inhibitor) combined to fulvestrant prolonged survival of PIK3CA-mutated patients [10]. At the molecular level, the ER $\alpha$ and PI3K pathways crosstalk at different levels [3]. At the genomic level, somatic activating mutations of the PIK3CA gene lead to abnormal PI3K/AKT/mTOR pathway activation [11]. In addition, PI3K inhibition increases ER $\alpha$ transcriptional activity via SGK1 and a feedback mechanism that attenuates the activity of PI3K inhibitors [12]. Beyond these genomic mechanisms of action, activation of the PI3K pathway in $\mathrm{BC}$ can occur via a non-genomic signaling pathway involving cytoplasmic ER $\alpha[13,14]$. Cytoplasmic ER $\alpha$ when complexed to Src and PI3K activates Akt, triggering proliferation and cell survival [13, 15-17]. Our team reported that methylation of ER $\alpha$ on residue $\mathrm{R} 260$ by the arginine methyltransferase PRMT1 is a prerequisite for its association with Src and PI3K and the activation of Akt [18, 19]. Subsequently, using the proximity ligation assay (PLA) methodology to detect in situ protein/protein interactions [20], we showed that this pathway, characterized by the formation of $\mathrm{ER} \alpha / \mathrm{Src} / \mathrm{PI} 3 \mathrm{~K}$, is present in normal breast tissue and is hyperactivated in aggressive breast tumors [21]. Moreover, we unveiled that $E R \alpha / S r c$ and $E R \alpha / P I 3 K$ interactions are associated with resistance to tamoxifen [22].

Taken together, these data introduced the concept that the non-genomic estrogen pathway, in addition to the presence of activating PIK3CA mutations, could affect the response to $\mathrm{PI} 3 \mathrm{~K}$ inhibitors associated with endocrine treatments.

In this study, we first evaluated $E R \alpha / \operatorname{Src}$ and $E R \alpha /$ PI3K interactions in a large cohort of $\mathrm{BC}$ patients. We then treated different PDX models of PIK3CA mutated and WT breast cancers with the PI3K inhibitor BYL719 combined to fulvestrant and explored their effect on tumor growth as well as on both genomic and nongenomic ER $\alpha$ pathways.

\section{Materials and methods}

\section{Human breast cancer sample collection}

The tumors from 440 patients of the Centre Léon Bérard (CLB) with invasive non-metastatic BC, whose clinical and biological data were available from the regularly updated institutional database, were analyzed. Written informed consent was obtained from each patient. The study protocol was approved by the institutional ethics committee. Patient characteristics are presented in the additional material (Additional file 2, Table S1). In 
our study, tumors exhibiting less than $10 \%$ of ER $\alpha$ positive cells were considered to be ER $\alpha$-negative tumors.

\section{Patient-derived xenografts}

Before PDX establishment, all patients had previously given their verbal informed consent for experimental research on residual tumor tissue available after histopathological analyses. PDX establishment was performed after the approval of the ethics committee of the Institut Curie. According to the French rules and the ethics committee of the Institut Curie, a written consent from patients to obtain residual tumor tissues is not required.

Nine breast cancer PDX models were used in this study. They were established from surgical specimens by grafting tumor fragments into the interscapular fat pad of nude mice as previously described [23, 24]. Female Swiss nude mice, 10 weeks old, were purchased from Charles River (Les Arbresles, France) and maintained under specific pathogen-free conditions. Their characteristics are described in the additional material (Additional file 3, Table S2). Their care and housing were in accordance with the institutional guidelines and the rules of the French Ethics Committee (project authorization no. 02163.02). Histological and IHC statuses (ER $\alpha, P R$, and HER2) were determined for the PDXs and compared with that of the patient tumor samples, as described elsewhere [23].

When tumors reached a volume of 60 to $200 \mathrm{~mm}^{3}$, mice were randomly assigned to the control or treatment groups, each group consisting of seven or eight mice. Fulvestrant (Faslodex ${ }^{\ominus}$, AstraZeneca, Macclesfield, UK) was administered by intramuscular injection at a dose of $200 \mathrm{mg} / \mathrm{kg}$ once a week. BYL719 was purchased from Medchemexpress and was administered orally at $35 \mathrm{mg} / \mathrm{kg} 5$ times per week. Tumor growth was evaluated by measuring two perpendicular diameters of tumors with a caliper twice a week. Individual tumor volumes were calculated as $V=a \times b^{2} / 2$, $a$ being the largest diameter and $b$ the smallest. Tumor growth inhibition (TGI) of treated tumors versus controls was calculated as the ratio of the mean tumor volume in the treated group to the mean tumor volume in the control group at the same time (end of the experiment). Statistical significance of TGI was calculated using the MannWhitney test by comparing the tumor volumes in the treated and control groups. Percent change in tumor volume was calculated for each tumor using the following formula: $[(\mathrm{Vf}-\mathrm{V} 0) / \mathrm{V} 0] \times 100$, where $\mathrm{V} 0$ is the initial volume (at the beginning of treatment) and $\mathrm{Vf}$ is the final volume (at the end of treatment). Classification of tumor response in waterfall plots: tumor regression, stabilization, and progression corresponded to a percent of volume change lower, equal or $>0$, respectively.
Tumor sampling was performed $24 \mathrm{~h}$ after the last treatment. No specific toxicity was reported in the experiments; neither diarrhea nor rash was observed, and treated mice did not display any important weight loss throughout the experiment time course.

\section{Antibodies}

\begin{tabular}{|c|c|c|c|c|}
\hline Antibodies & Supplier & Origin & $\begin{array}{l}\text { Dilution for } \\
\text { PLA }\end{array}$ & $\begin{array}{l}\text { Dilution } \\
\text { for IHC }\end{array}$ \\
\hline PI3K p85 ab-22653 & Abcam & mouse & $1 / 30$ & \\
\hline c-Src (B12) sc-8056 & SCBT & mouse & $1 / 150$ & \\
\hline ERa (HC20) sc-542 & SCBT & rabbit & $1 / 75$ & \\
\hline ERa (SP1) 05278406001 & Roche & rabbit & & $\begin{array}{l}\text { Ready to } \\
\text { use }\end{array}$ \\
\hline p-AKT (Ser473) 4060 & CST & rabbit & & $1 / 75$ \\
\hline $\begin{array}{l}\text { p-S6 riboprotein } \\
\text { (Ser235/236) } 4857\end{array}$ & CST & rabbit & & $1 / 100$ \\
\hline PTEN 9559 & CST & rabbit & & $1 / 100$ \\
\hline PI3K p85 05-212 & Millipore & mouse & & $1 / 200$ \\
\hline
\end{tabular}

\section{Proximity ligation assay in tissues}

This technology, first published in 2006 [20], enables the in situ visualization of protein-protein interactions and was supplied by Sigma. Paraffin-fixed tumor tissues incorporated in TMA blocks were initially sectioned and incubated in a hydrogen peroxide solution, for $5 \mathrm{~min}$ at room temperature, to avoid peroxidase quenching. The antibody labeling steps were similar to those described above. For antibody detection, the probes were labeled with horseradish peroxidase after two washes in high purity water. A nuclear staining solution was added to the slides and incubated $2 \mathrm{~min}$ at room temperature. After washing the slides for $10 \mathrm{~min}$ under running tap water, the samples were consecutively dehydrated in ethanol and xylene. Samples were mounted in a non-aqueous mounting medium and visualized under a bright-field microscope. The protocol has already been optimized for $E R \alpha / S r c$ and $E R \alpha / P I 3 K$ interactions $[18,21,25]$.

\section{Image acquisition and analysis}

The hybridized fluorescent slides were viewed under a Zeiss Axio Imager M2 microscope. Images of three independent zones on each tumor were acquired under identical conditions at $\times 40$ magnification. At least, 500 cells were counted per tumor.

\section{Statistical analysis}

$\mathrm{ER} \alpha / \mathrm{Src}$ and $\mathrm{ER} \alpha / \mathrm{PI} 3 \mathrm{~K}$ interaction in invasive breast cancer samples (by bright-field microscopy) was quantified as the mean number of dots (denoting interaction) per cell. For the sake of correlation and survival analyses, 
a cutoff for interaction was defined at the most discriminative difference in DFS and OS as calculated by Kaplan-Meier estimates. Accordingly, ER $\alpha / \mathrm{Src}$ interaction was defined as high if the mean number of dots/ cell $>10$ and low if $\leq 10$ dots/cell, while ER $\alpha /$ PI3K interaction was high if $>9$ dots/cell and low if $\leq 9$ dots/cell. Correlations between the 2 biomarkers ER $\alpha / \operatorname{Src}$ and ER $\alpha /$ PI3K were studied. The Pearson's correlation coefficient was presented with asterisks highlighting its significance $\left(" P<0.05\right.$; ${ }^{* *} P<0.01$; $\left.{ }^{* * *} P<0.001\right)$. Associations between categorical variables were studied using Pearson's chi-square test. Overall survival (OS) defined as the time from diagnosis to death or date of last followup and disease-free survival (DFS) defined as the time from diagnosis to death or relapse or date of last followup (for censored patients) were studied.

Survival curves were estimated by the Kaplan-Meier method and compared between the groups with different interaction levels using the log-rank test.

\section{RT-QPCR analysis}

RNA extraction was performed as previously described $[26,27]$. Quantitative values were obtained from the number of the cycle (Ct value) at which the increase in the fluorescent signal associated with the exponential growth of PCR products was initially detected by the laser detector of the ABI Prism 7900 sequence detection system (Perkin-Elmer Applied Biosystems, Foster City, $\mathrm{CA})$, using the PE biosystems analysis software according to the manufacturer's manuals.

For gene normalization, we used the human TATA box-binding protein (TBP, GenBank accession no. NM 003194). We used protocols for cDNA synthesis and PCR amplification described in detail elsewhere [28]. The results, expressed as $\mathrm{N}$-fold differences in target gene expression relative to the TBP gene and termed "Ntarget," were determined as Ntarget $=2^{\Delta \text { Ctsample }}$, where the $\Delta \mathrm{Ct}$ value of the sample is obtained by subtracting the average $\mathrm{Ct}$ value of the target gene from the average $\mathrm{Ct}$ value of TBP gene.

\section{IHC experiments}

Xenografted tumors were fixed in 10\% neutral buffered formalin, paraffin embedded, and hematoxylin-eosinsaffron (HES) stained. Outgrowths were analyzed by immunohistochemistry (IHC) for the expression of biomarkers. Immunostaining was performed on a Discovery XT Platform (Ventana Medical System, Tucson, AZ, part of Roche Diagnostics) with antigen retrieval using either EDTA buffer, pH 8.0 (CC1, Ventana Medical System) or citrate buffer $10 \mathrm{mM}, \mathrm{pH} 6.0$ (CC2, Ventana Medical System). Primary antibodies were mostly monoclonal rabbit antibodies, and paired slides immunostained with rabbit IgG were used as negative controls. Incubation and color development involved anti-rabbit multimer secondary antibody (horseradish peroxidase complex) with DAB (3,30-diaminobenzidine tetrahydrochloride) as a substrate (ChromoMap Kit with Anti-rabbit OmniMap, Ventana Medical System). The IHC slides were scanned using a Pannoramic SCAN II (3DHISTECH). We then used the HALO software (Indica Labs) to quantify the expression levels of ER $\alpha$, pAkt (S473), and p-S6 riboprotein (S235/6).

\section{Results}

Clinicopathological characteristics of the patient cohort Among the 440 patients, 433 had complete clinical data, 430 were assessable for $\mathrm{ER} \alpha / \mathrm{Src}$ interaction, and 417 were assessable for $\mathrm{ER} \alpha / \mathrm{PI} 3 \mathrm{~K}$ interaction. The median age at diagnosis was 57.9 years (range 30.4 to 87.4 years). Regarding the tumor stage, $41.8 \%$ of patients had tumors beyond $20 \mathrm{~mm}$, and $57.5 \%$ displayed axillary $\mathrm{LN}$ metastasis. Only $18.9 \%$ of patients had SBR grade I tumors, $47.8 \%$ had grade II tumors, and $33.3 \%$ grade III tumors. ER was positive in $87.1 \%$, PR in $74.8 \%$, and HER2 was overexpressed in $7.2 \%$ of the cohort. Table S1 shows the clinico-pathological characteristics of the tested patient cohort (433 patients).

Representative micrographs of tumor cells with high (tumor\#2) and low levels of interaction (tumor\#1) of $E R \alpha / \operatorname{Src}$ and $E R \alpha / P I 3 K$ are shown in Fig. 1a. ER $\alpha / \operatorname{Src}$ interaction was high (>10 dots) in 174 cases (40.5\%), while 256 of cases (59.5\%) showed low levels of interaction ( $\leq 10$ dots). ER $\alpha / \mathrm{PI} 3 \mathrm{~K}$ interaction was high (> 9 dots) in 156 cases (37.4\%), while 261 of cases $(62.6 \%)$ displayed low levels of interaction ( $\leq 9$ dots). Interestingly, we observed a positive association between $\mathrm{ER} \alpha / \mathrm{Src}$ and $\mathrm{ER} \alpha / \mathrm{PI} 3 \mathrm{~K}$ interactions $(P<0.001)$ (Table 1). We observed no correlation between high levels of interaction of either ER $\alpha / \operatorname{Src}$ (Table 2) or ER $\alpha /$ PI3K (Table 3) with any of the traditional prognostic parameters of breast cancer.

\section{High levels of ERa/PI3K interaction are associated with poorer breast cancer patient outcome}

No significant impact on either OS $(\mathrm{HR}=1.24 ; 95 \% \mathrm{CI}$ $0.79-1.94 ; P=0.343)$ or DFS (HR $=1.21$; 95\% CI $0.83-$ $1.75 ; P=0.325)$ was noted for patients displaying high or low levels of $E R \alpha / S r c$ interactions (Fig. 1b). Conversely, $\mathrm{ER} \alpha / \mathrm{PI} 3 \mathrm{~K}$ interaction predicted a trend towards poorer OS and DFS (Fig. 1c), with an 8-year OS rate of $79.2 \%$ in patients with low levels versus $72.4 \%$ in patients with high levels of $\mathrm{ER} \alpha / \mathrm{PI} 3 \mathrm{~K}$ interaction $(\mathrm{HR}=1.55$; $95 \% \mathrm{CI}$ $0.99-2.44 ; P=0.055$ ) and an 8 -year DFS rate of $79.2 \%$ in patients with low levels versus $72.4 \%$ in patients with high levels of $\mathrm{ER} \alpha / \mathrm{PI} 3 \mathrm{~K}$ interaction $(\mathrm{HR}=1.35$; $95 \% \mathrm{CI}$ 0.93-1.97; $P=0.116$ ). 
a
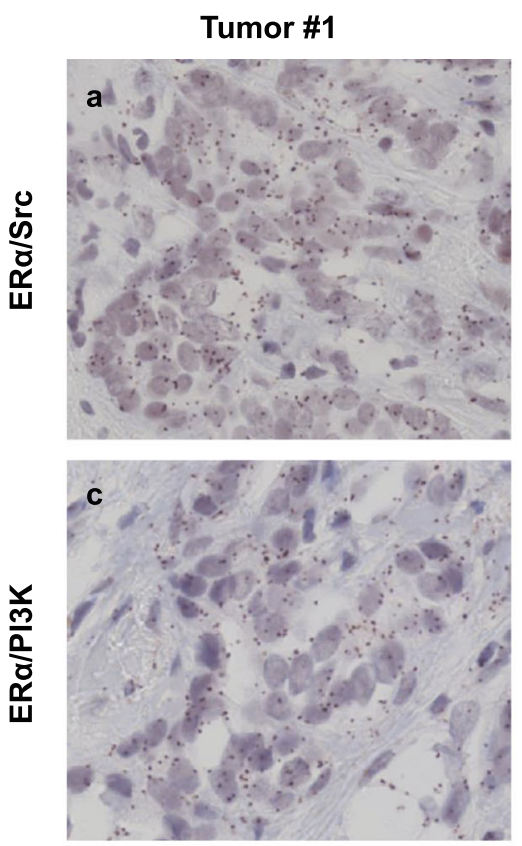

b

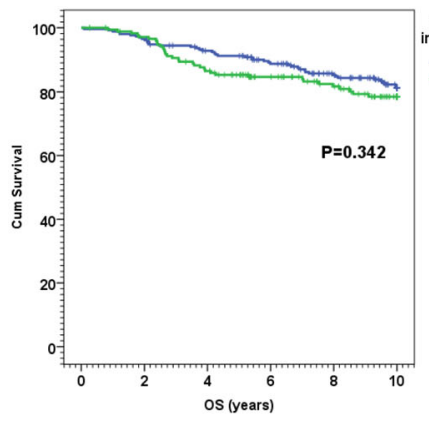

C

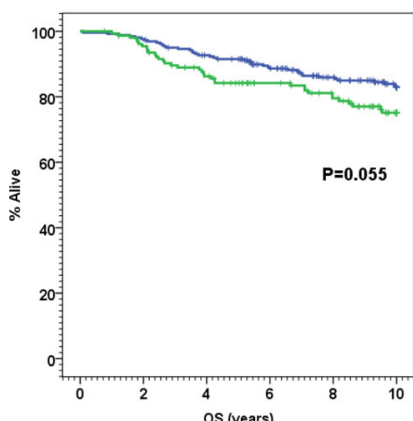

Tumor \#2
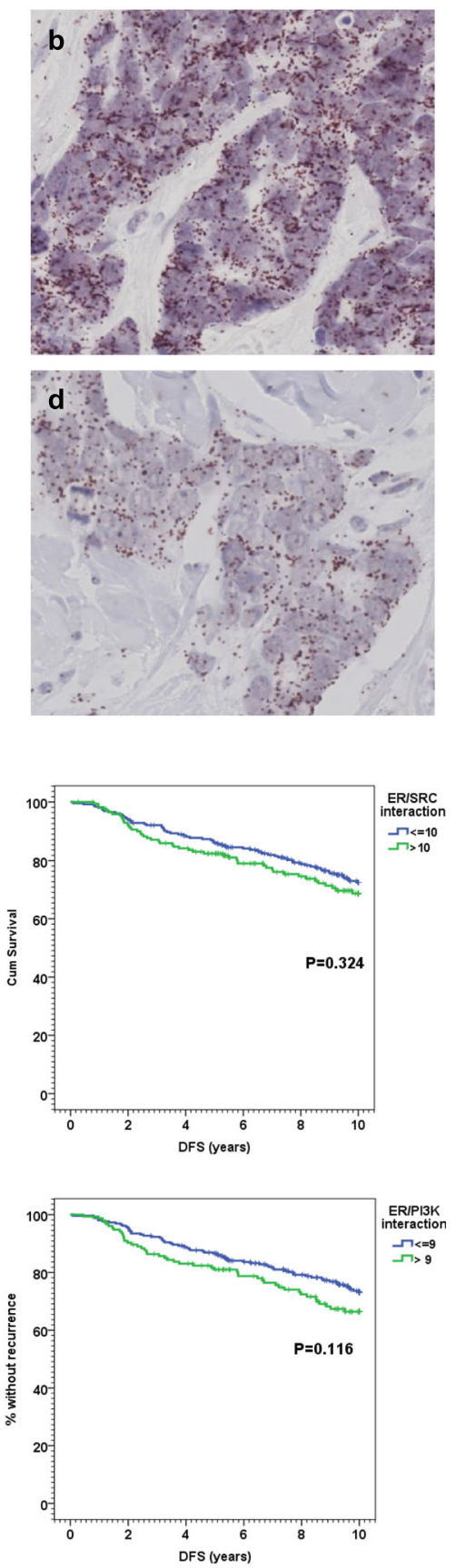

Fig. $1 \mathrm{ERa} / \mathrm{Src}$ and ERa/PI3K interactions in human tumoral breast samples. a ERa/Src (a, b) and ERa/PI3K (c, d) interactions were detected by proximity ligation assay (PLA) on two formalin-fixed paraffin-embedded breast tumor sections. The experiments were performed on two serial sections from the same tumor (Obj $\times 40)$. b Kaplan-Meier estimates of OS and DFS according to ERa/Src interaction. c Kaplan-Meier estimates of OS and DFS according to the ERa/PI3K interaction

Table 1 Correlation between ERa/Src and ERa/PI3K interactions

\begin{tabular}{|c|c|c|c|c|}
\hline Variable & & ERa/PI3K $\leq 9$, no. (\%) & ERa/PI3K >9, no. (\%) & $P$ \\
\hline \multirow[t]{2}{*}{$\mathrm{ERa} / \mathrm{SrC}$} & Low $(\leq 10)$ & $181(69.6)$ & $68(44.2)$ & $<0.001$ \\
\hline & High (> 10) & 79 (30.4) & $86(55.8)$ & \\
\hline
\end{tabular}


Table 2 Distribution of clinical parameters according to ERa/Src expression

\begin{tabular}{|c|c|c|c|c|}
\hline Variable & & $\mathrm{ERa} / \mathrm{SRC} \leq 10$, no. (\%) & ERa/SRC >10, no. (\%) & $P^{*}$ \\
\hline \multirow[t]{2}{*}{ Age groups } & $\leq 50$ years & $76(29.7)$ & $35(20.1)$ & 0.026 \\
\hline & $>50$ years & $180(70.3)$ & $139(79.9)$ & \\
\hline \multirow[t]{2}{*}{ T. size } & $\leq 2 \mathrm{~cm}$ & $152(59.4)$ & $97(55.7)$ & 0.455 \\
\hline & $>2 \mathrm{~cm}$ & $104(40.6)$ & $77(44.3)$ & \\
\hline \multirow[t]{2}{*}{ LN invasion } & No & $108(42.2)$ & $74(42.5)$ & 0.944 \\
\hline & Yes & $148(57.8)$ & $100(57.5)$ & \\
\hline \multirow[t]{3}{*}{ SBR grade } & Gr 1 & $44(17.2)$ & $37(21.3)$ & 0.394 \\
\hline & Gr 2 & $129(50.4)$ & $77(44.3)$ & \\
\hline & Gr 3 & $83(32.4)$ & $60(34.5)$ & \\
\hline \multirow[t]{2}{*}{ ERa status } & Negative & $34(13.3)$ & $21(12.1)$ & 0.712 \\
\hline & Positive & $222(86.7)$ & $153(87.9)$ & \\
\hline \multirow[t]{2}{*}{ PR status } & Negative & $61(23.8)$ & $47(27.0)$ & 0.455 \\
\hline & Positive & $195(76.2)$ & $127(73.0)$ & \\
\hline \multirow[t]{2}{*}{ HER2 status } & Negative & $238(83.7)$ & $157(91.3)$ & 0.345 \\
\hline & Positive & $16(6.3)$ & $15(8.7)$ & \\
\hline \multirow[t]{4}{*}{ Breast Cancer subtype } & Luminal A & $146(57.0)$ & $95(54.6)$ & 0.876 \\
\hline & Luminal B & $76(29.7)$ & $58(33.3)$ & \\
\hline & HER2 rich & $7(2.7)$ & $4(2.3)$ & \\
\hline & TNBC & $27(10.5)$ & $17(9.8)$ & \\
\hline \multirow[t]{2}{*}{ Type of adjuvant hormonal } & Tamoxifen & $93(42.3)$ & $78(52.3)$ & 0.057 \\
\hline & $\mathrm{Al}$ & $127(57.7)$ & $71(47.7)$ & \\
\hline
\end{tabular}

Table 3 Distribution of clinical parameters according to the ERa/PI3K expression

\begin{tabular}{|c|c|c|c|c|}
\hline Variable & & $\begin{array}{l}\mathrm{ERa} / \mathrm{PI} 3 \mathrm{~K} \leq 9, \\
\text { no. }(\%)\end{array}$ & $\begin{array}{l}\text { ERa/PI3K >9, } \\
\text { no. (\%) }\end{array}$ & $P$ \\
\hline \multirow[t]{2}{*}{ Age groups } & $\leq 50$ years & $75(28.7)$ & $36(23.1)$ & 0.206 \\
\hline & $>50$ years & $186(71.3)$ & $120(76.9)$ & \\
\hline \multirow[t]{2}{*}{ T. size } & $\leq 2 \mathrm{~cm}$ & $157(60.2)$ & $84(53.8)$ & 0.207 \\
\hline & $>2 \mathrm{~cm}$ & $104(39.8)$ & $72(46.2)$ & \\
\hline \multirow[t]{2}{*}{ LN invasion } & No & $115(44.1)$ & $60(38.5)$ & 0.262 \\
\hline & Yes & $146(55.9)$ & $96(61.5)$ & \\
\hline \multirow[t]{3}{*}{ SBR grade } & Gr 1 & $54(20.7)$ & $25(16.0)$ & 0.069 \\
\hline & Gr 2 & $130(49.8)$ & $68(43.6)$ & \\
\hline & Gr 3 & 77 (29.5) & $63(40.4)$ & \\
\hline \multirow[t]{2}{*}{ ER status } & Negative & $31(11.9)$ & $22(14.1)$ & 0.509 \\
\hline & Positive & $230(88.1)$ & $134(85.9)$ & \\
\hline \multirow[t]{2}{*}{ PR status } & Negative & $60(23.0)$ & $45(28.8)$ & 0.182 \\
\hline & Positive & $201(77.0)$ & $111(71.2)$ & \\
\hline \multirow[t]{2}{*}{ HER2 status } & Negative & $238(93.0)$ & $144(92.3)$ & 0.802 \\
\hline & Positive & $18(7.0)$ & $12(7.7)$ & \\
\hline \multirow[t]{4}{*}{ Breast Cancer subtype } & Luminal A & $155(59.4)$ & $77(49.4)$ & 0.249 \\
\hline & Luminal B & $75(28.7)$ & $57(36.5)$ & \\
\hline & HER2 rich & $6(2.3)$ & $5(3.2)$ & \\
\hline & TNBC & $25(9.6)$ & $17(10.9)$ & \\
\hline \multirow[t]{2}{*}{ Type of adjuvant hormonal } & Tamoxifen & $97(57.1)$ & $65(49.2)$ & 0.151 \\
\hline & $\mathrm{Al}$ & $129(42.9)$ & 67 (50.8) & \\
\hline
\end{tabular}


Targeting estrogen genomic and non-genomic signaling in ERa-positive PDX models

Based on the present data and our previous results [21, 22], we hypothesized that the estrogen non-genomic pathway could represent a therapeutic target in $\mathrm{BC}$ and particularly in endocrine-resistant $\mathrm{ER} \alpha+\mathrm{BCs}$. To test our hypothesis, we targeted non-genomic signaling using a combination of endocrine therapy (fulvestrant), known to degrade ER $\alpha$, inhibiting transcription of its target genes, and a PI3K inhibitor, as our team formerly showed that inhibiting PI3K activity disrupted the complex containing ER $\alpha / \mathrm{PI} 3 \mathrm{~K}$ and its downstream signaling in MCF-7 cells [21]. As our previous results were obtained with LY294002, an inhibitor not used in clinics, we studied the effect of three other PI3K inhibitors on MCF-7 cells and found that BYL719 was the most effective at decreasing the interaction of ER $\alpha$ with PI3K (Additional file 4, Fig. S1). This inhibitor was thus selected for further in vivo experiments. We hence evaluated the efficacy of fulvestrant alone, BYL719 alone, or BYL719 + fulvestrant (combination) in 6 PDX models of $\mathrm{ER} \alpha+$ breast cancers. The characteristics of the different PDXs are summarized in the Additional file 3 Table S2 and Additional file 5 Fig. S2. Five of these models were established from primary breast tumors and one from bone metastasis. Three models (HBCx-86, $\mathrm{HBCx}-91$, and $\mathrm{BC} 1111$ ) are PIK3CA mutated (HBCx-86: p.E545K HBCX-91 and BC1111: p.H1047R).

\section{The hormone-sensitive ERa+ PIK3CA WT HBCX-34 PDX model}

In this model, treatment with fulvestrant for 3 months resulted in tumor regression in 5/8 xenografts, stable disease in 1 xenograft, and complete response in 1 xenograft, though BYL719 alone had only a mild but significant effect in comparison (Fig. 2a). Interestingly, tumor response further increased in the combination group ( $P=0.01$, Mann-Whitney test) with $6 / 10$ xenografts displaying complete responses, 3 tumor regression, and 1 stable disease (Fig. 2b).

At the level of ER $\alpha$ non-genomic signaling, the ER $\alpha /$ PI3K interaction was significantly reduced by fulvestrant alone or when combined to BYL719, though BYL719 alone had no effect (Fig. 2c). The analysis of some estrogen-regulated genes (ERG) showed a nonsignificant increase in PGR, GREB1, and TFF1 gene expression in BYL719-treated xenografts and a significant decrease in the expression of the same genes in xenografts treated with fulvestrant or the combination (Fig. 2d). ESR1 expression remained unchanged. IHC staining validated that $E R \alpha$ expression decreased upon fulvestrant treatment and that BYL719 inhibited downstream PI3K signaling only when combined with fulvestrant, as evidenced by P-S6 riboprotein (S235/6) expression (Fig. 2e, Additional file 6 Fig. S3). However, as this tumor does not express P-Akt (S473), we were unable to confirm the efficacy of BYL719 on PI3K signaling.

\section{The hormone-sensitive ERa+ PIK3CA WT HBCX-3 and PIK3CA mut $H B C X-86$ PDX models}

These two models responded partially to BYL719 and fulvestrant alone, whereas their combination clearly increased this anti-tumoral effect. In the PDX $\mathrm{HBCx}-3$, the combination of BYL719 and fulvestrant did not completely inhibit tumor growth (Fig. 3a), although this was significantly decreased compared to the control (TGI of $62 \%$ and 65\%, respectively). The PIK3CA-mutated HBCx-86 model responded to the combination by exhibiting remarkable tumor regression (Fig. 3b). For these models, ER $\alpha /$ PI3K interaction was efficiently disrupted with fulvestrant but not with BYL719 alone (Fig. 3c, d). The combination strongly decreased ER $\alpha / \mathrm{PI} 3 \mathrm{~K}$ interaction in the HBCx-3 model, whereas it had no effect on the HBCx-86 model. ERG remained largely unaffected by the treatment (Fig. 3e, f). IHC staining revealed that for both models, fulvestrant treatment decreased ER $\alpha$ expression (Fig. 3g, h, Additional file 7, Fig S4, Additional file 8 Fig S5). However, regarding BYL719 efficacy, it had no effect on the HBCx-3 model (Fig. 3g, Additional file 7 Fig. S4), whereas it significantly decreased P-S6 riboprotein (S235/6) staining in HBCx86 (Fig. 3h, Additional file 8 Fig S5). Unfortunately, we could not confirm this result, as Akt staining was too low. These results suggest that the effects of fulvestrant on tumor growth are potentiated following PI3K inhibition in the context of estrogen non-genomic signaling.

\section{The fulvestrant-resistant ERa+ PIK3CA WT TamR HBCX-22 and PIK3CA mut BC1111 models}

The HBCx-22 TamR model did not respond significantly to BYL719 alone or in combination with fulvestrant (Fig. 4a). Surprisingly, the BC1111 model was resistant to BYL719, but the combination strongly inhibited tumor growth (TGI 79\%, $P<0.0001$ ) (Fig. 4b). Interestingly, in the two models, $\mathrm{ER} \alpha / \mathrm{PI} 3 \mathrm{~K}$ interaction was not significantly affected by the treatment, fulvestrant having an opposite effect in the HBCx-22 TamR model by significantly increasing this interaction (Fig. 4c, d), corroborating our previous findings [22]. The expression of ERG diminished following the administration of fulvestrant or of the combination treatment, whereas it increased with BYL719 alone (Fig. 4e, f). IHC staining of the $\mathrm{HBCx}-22$ TamR model revealed that fulvestrant strongly inhibited ER $\alpha$ nuclear expression, while BYL719 had no effect on PI3K signaling (Fig. 4g, Additional file 9 Fig S6). With regard to the BC1111 model, fulvestrant triggered a decrease in ER $\alpha$ expression, while BYL719 


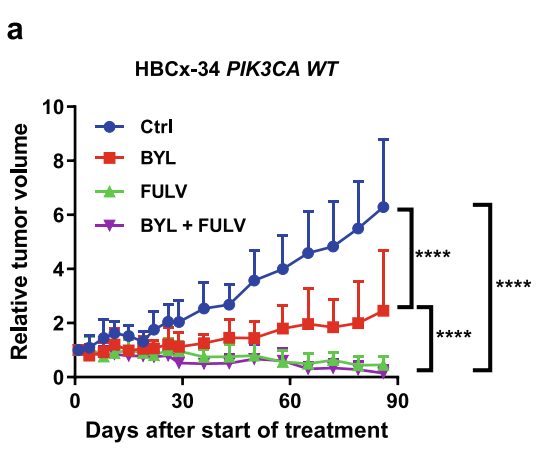

b

c

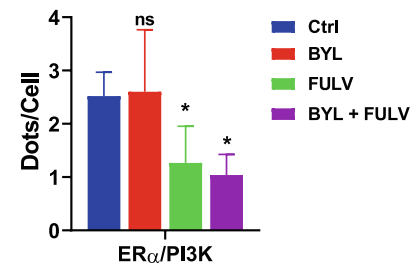

e d
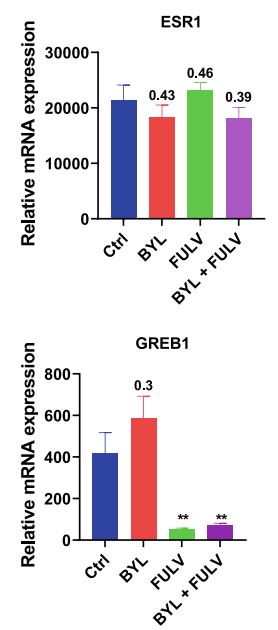

p-S6
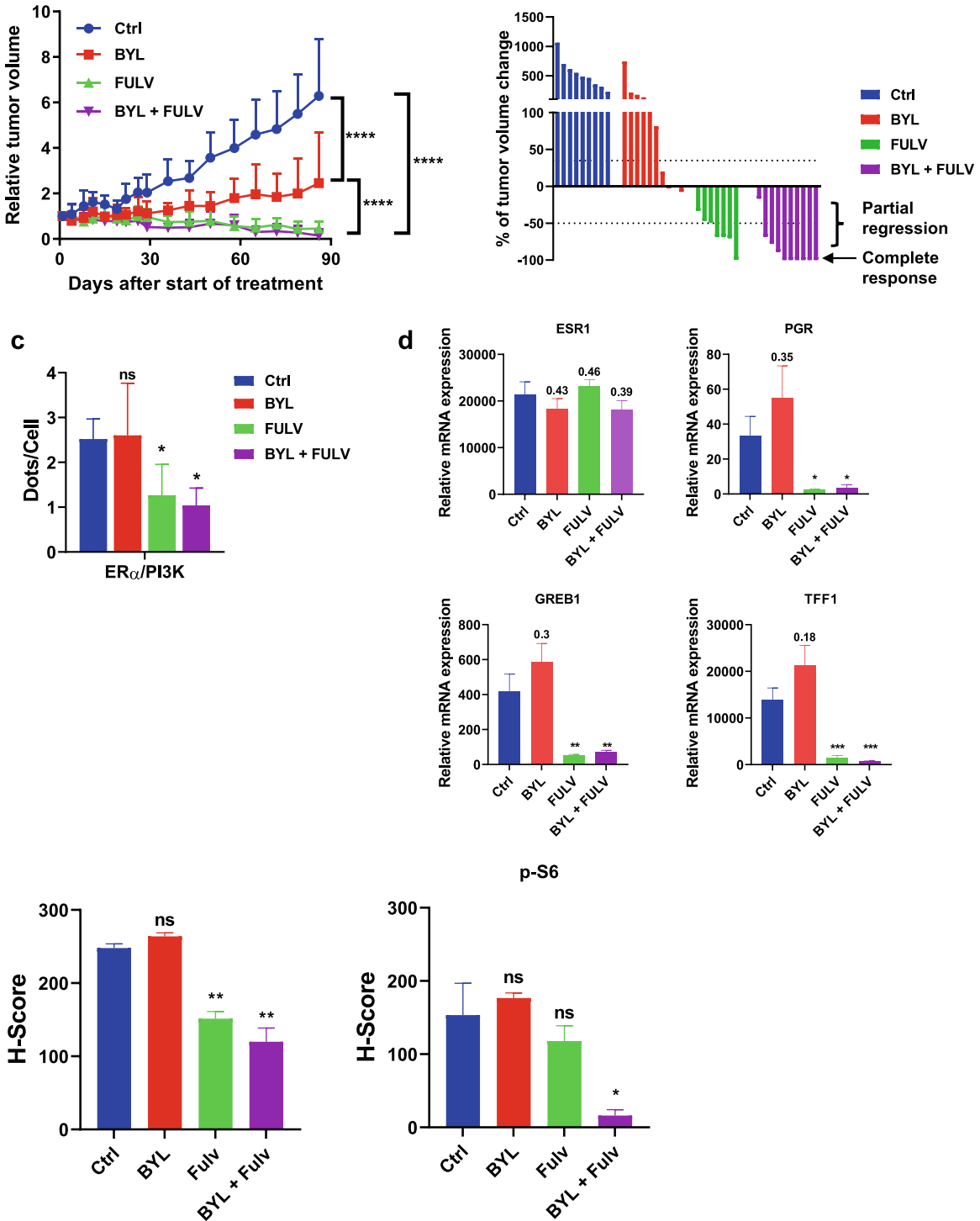

Fig. 2 In vivo drug response to BYL719 or fulvestrant alone and combined in the HBCX-34 PDX model. a Effect of the different treatments on HBCX-34 tumor growth. Each treatment included 10 mice; the $y$-axis indicates the mean of RTV + SD. $\mathbf{b}$ Waterfall plot representing the percent of change in tumor volume from baseline in individual HBCX-34 xenografts in the different treatment groups. c PLA was performed on treated tumors embedded in paraffin to study the interactions between ERa and PI3K. Quantification was performed by counting the number of signals per cell in five independent zones of the section ( $n>500$ cells counted/tumor). Significance ( $P$ value) between treatments was determined using the Student $t$ test. ns, non-significant; ${ }^{*} P<0.05$; ${ }^{*} P<0.01$. $\mathbf{d}$ Expression of estrogen-regulated genes (ERG) analyzed by RT-QPCR in PDX tumor samples $(N=4)$. e $I H C$ staining was performed on formalin-fixed paraffin-embedded PDX tumors using anti-ERa and anti-P-S6 riboprotein (S235/6) antibodies. Quantification of highly, medium, and negative cells was performed as described in the "Materials and methods" section. Significance ( $P$ value) between treatments and controls were performed using the $t$ test. ns:not significant

efficiently inhibited the PI3K pathway (Fig. 4h, Additional file 10 Fig S7).

The fulvestrant-resistant ERa+ PIK3CA mut $H B C X-91$ model This PDX model was engrafted with a tumor from a patient expressing a low level of ER $\alpha$ and harboring a
PI3KCA mutation. This model was resistant to fulvestrant alone but responded to BYL719 alone or in combination with fulvestrant, by inducing a stable lowgrade disease (Fig. 5a). We observed a significant increase in ER $\alpha / \mathrm{PI} 3 \mathrm{~K}$ interaction upon fulvestrant treatment, whereas BYL719 alone or in combination had no 


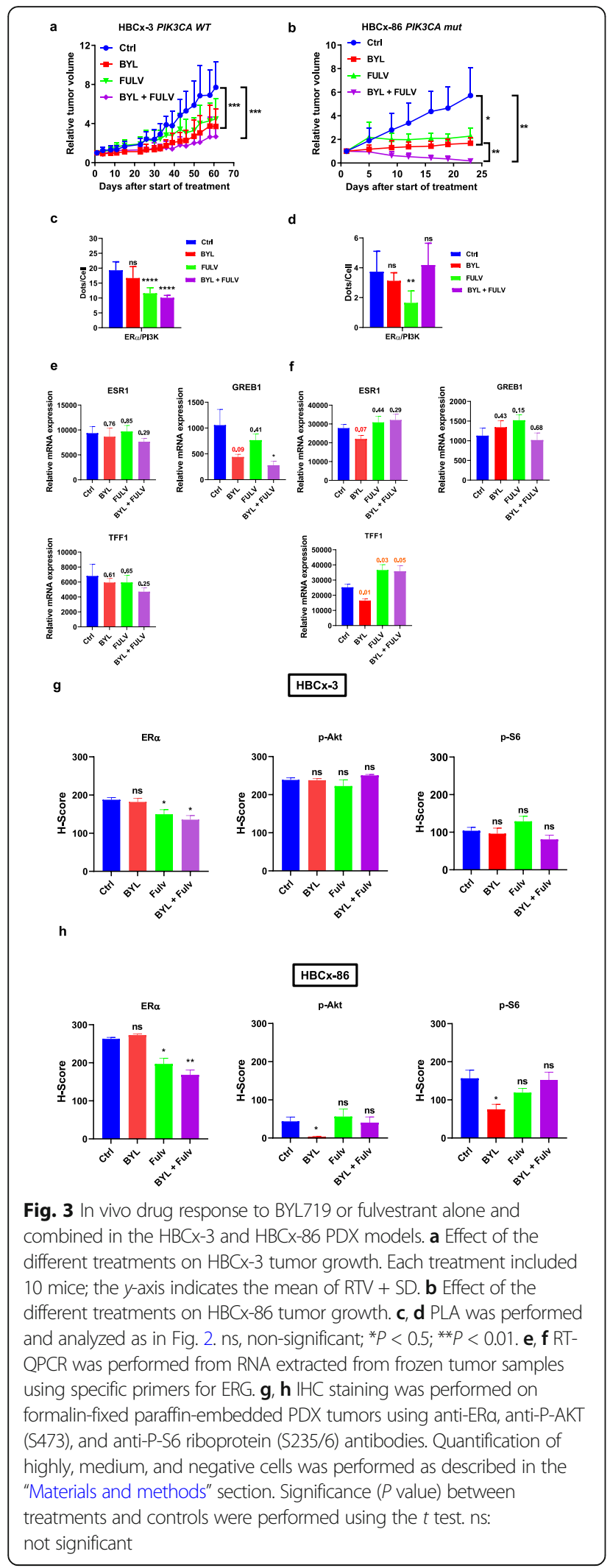

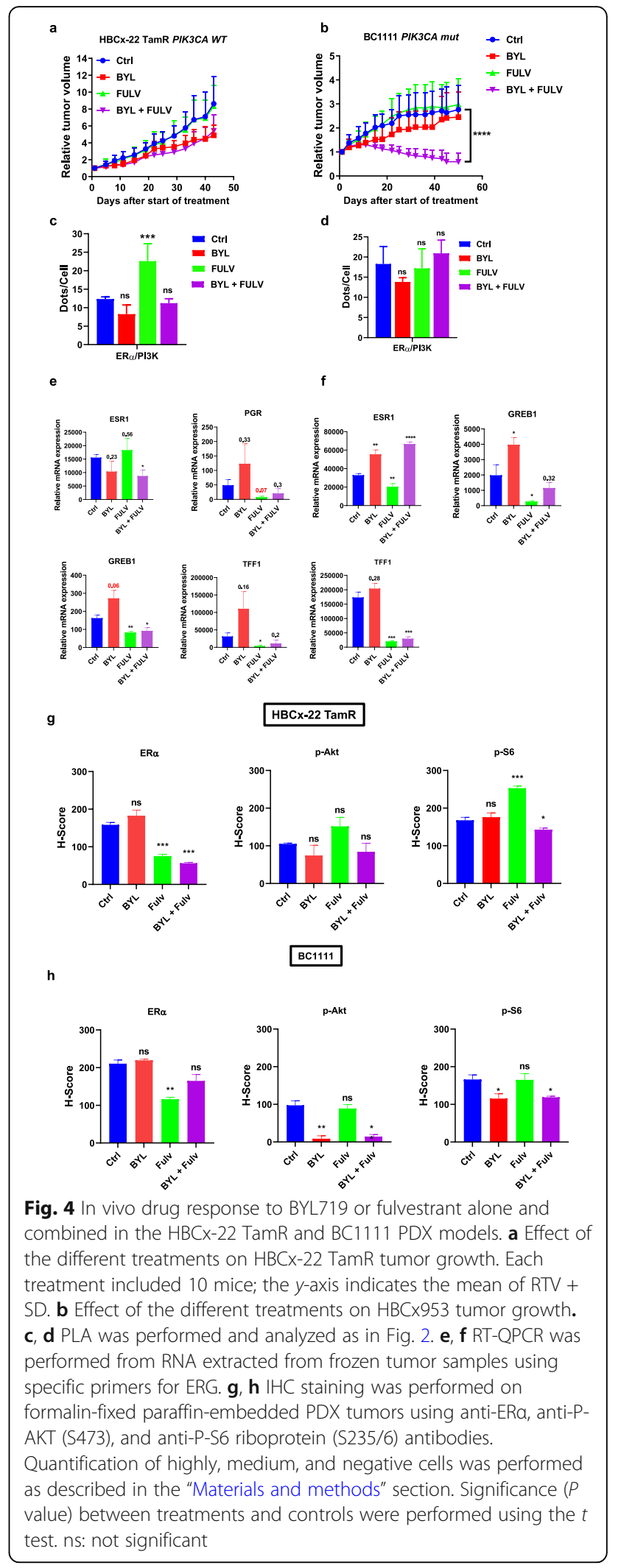




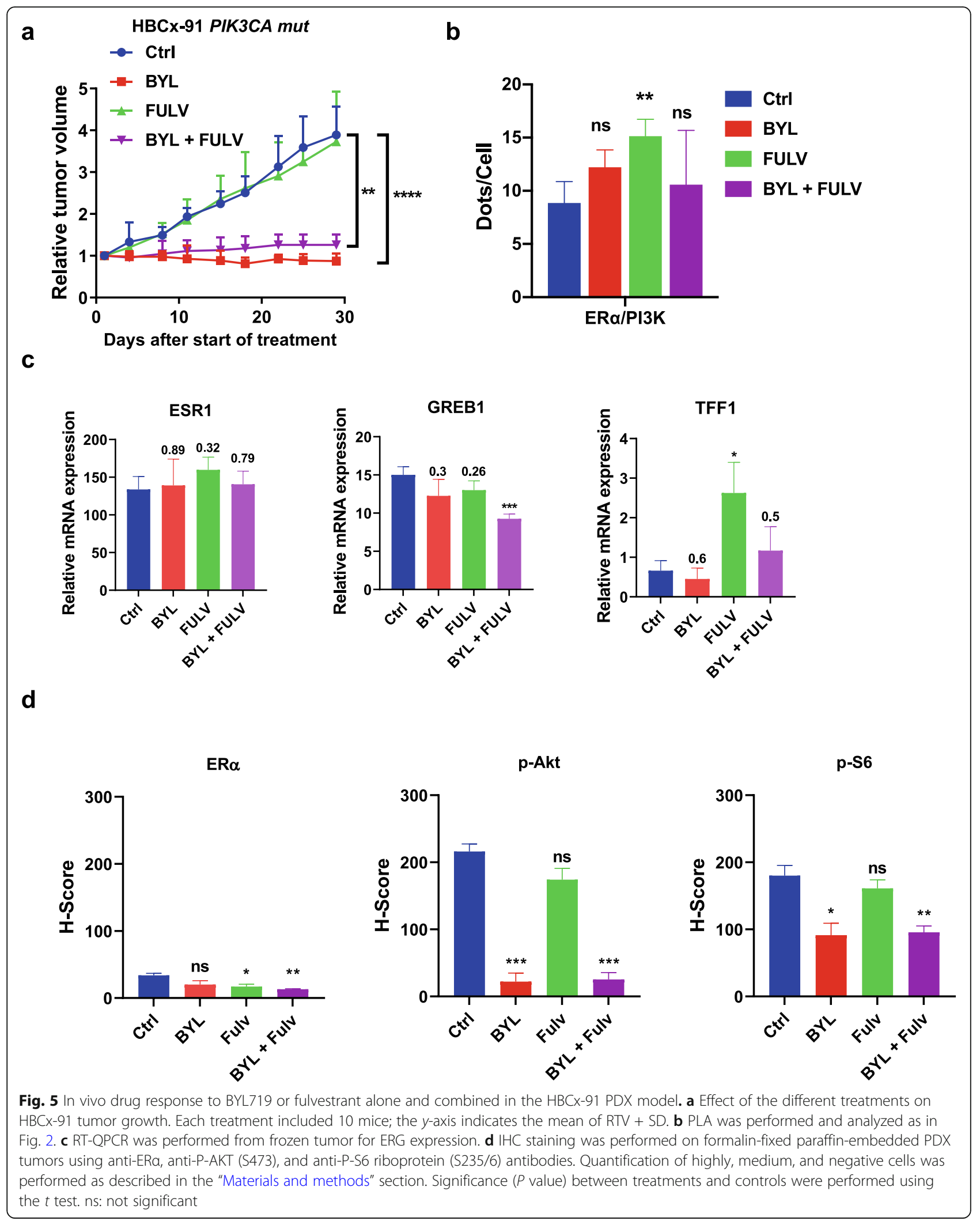


effect (Fig. 5b). The expression of ERG was not significantly affected by the different treatments (Fig. 5c). The IHC staining confirmed that ER $\alpha$ was faintly expressed in the nucleus of tumoral cells (Fig. 5d). Fulvestrant induced a significant decrease in ER $\alpha$ expression and BYL719 efficiently targeted the PI3K pathway (Fig. 5d, Additional file 11 Fig S8).

\section{Targeting estrogen non-genomic signaling in ERa- negative PDX models}

As the estrogen non-genomic complex is also activated in ER $\alpha$-negative breast tumors [21] and the PI3K pathway is active in TNBC, we tested the combination of BYL719 + fulvestrant in 3 ER $\alpha$-negative PDX models.

In the $\mathrm{HBCx}-17$ model (WT for PIK3CA), only the combination of BYL719 + fulvestrant inhibited tumor growth with a TGI of $64 \%(P=0.03$, Mann-Whitney $t$ test), although no tumor regression was observed (Fig. 6a). Interestingly, fulvestrant and BYL719 alone significantly decreased ER $\alpha / \mathrm{PI} 3 \mathrm{~K}$ formation, whereas the combination had no cumulative effect (Fig. 6b). IHC analysis revealed a similar decrease in P-S6 riboprotein (S235/236) expression in tumors treated with BYL719 alone or combined with fulvestrant, although it was less clear for P-Akt (Fig. 6c, Additional file 11 Fig S9).

In the HBCx-66 model (WT for PI3KCA), fulvestrant had a modest effect on tumor growth, while administration of BYL719 alone or in combination led to a strong decrease in tumor volume (Fig. 6d). BYL719 and fulvestrant significantly decreased ER $/ \mathrm{PI} 3 \mathrm{~K}$ interaction whereas the combination had no significant effect (Fig. 6e). Similarly to the previous ER $\alpha$ - model, BYL719 showed a non-significant decrease in P-AKT (S473) and P-S6 riboprotein (S235/236) staining (Fig. 6f, Additional file 12 Fig S10).

In the $\mathrm{HBCX}-90$ PDX (PI3KCA mutated), treatment with fulvestrant had no effect on tumor growth, whereas BYL719 or the combination significantly decreased tumor volume. Interestingly, in this model resistant to fulvestrant, the anti-estrogen had no effect on ER $\alpha / \mathrm{PI} 3 \mathrm{~K}$ interactions (Fig. 6h). Conversely, BYL719 significantly inhibited the downstream PI3K pathway but did not affect ER $\alpha /$ PI3K interaction (Fig. 6i, Additional file 13 Fig S11).

In conclusion, in ER $\alpha$-negative tumors, the effect of fulvestrant on tumor growth is likely linked to its ability to disrupt ER $\alpha$ interaction with PI3K.

\section{Discussion}

Based on our results and other existing literature, we postulated that the components of estrogen nongenomic signaling could constitute both new prognostic markers and new therapeutic targets. In this study, we sought to validate the activation of this pathway in aggressive breast cancers in a new cohort of breast tumor patients. ER $\alpha / \mathrm{Src} / \mathrm{PI} 3 \mathrm{~K}$ being a hallmark of nongenomic signaling, we studied $\mathrm{ER} \alpha / \mathrm{Src}$ and $\mathrm{ER} \alpha / \mathrm{PI} 3 \mathrm{~K}$ by in situ PLA in samples of 440 invasive breast tumors. Interestingly, we found that their high level of expression was correlated with a trend to poorer patient survival, $\mathrm{ER} \alpha / \mathrm{PI} 3 \mathrm{~K}$ being associated with the most pronounced effects. These data corroborate those obtained in the first cohort of $175 \mathrm{BCs}$ [21] and argue in favor of targeting $\mathrm{ER} \alpha / \mathrm{PI} 3 \mathrm{~K}$ in in vivo models of $\mathrm{BCs}$.

As a proof-of-concept, we decided to target ER $\alpha$ / PI3K interactions using an anti-estrogen (fulvestrant) or a PI3K inhibitor alone (BYL719) or in combination in 6 models of $\mathrm{ER} \alpha+$ and $3 \mathrm{ER} \alpha-\mathrm{BC}$ PDXs. For the ER $\alpha$-positive models, we evaluated their effect on tumor growth as well as on estrogen nongenomic signaling (by studying ER $\alpha / \mathrm{PI} 3 \mathrm{~K}$ interaction) and on genomic signaling (by studying the expression of ER $\alpha$ target genes). For the ER $\alpha$ negative models, we assessed the efficacy of treatments on tumor growth and on ER $\alpha / \mathrm{PI} 3 \mathrm{~K}$ interactions. We decided to use a PI3K inhibitor acting predominantly against $\mathrm{PI} 3 \mathrm{~K} \alpha$, as it has been largely shown by our team and others that treating $\mathrm{BC}$ cells with PI3K inhibitors disrupts $\mathrm{ER} \alpha / \mathrm{PI} 3 \mathrm{~K}$ interactions in $\mathrm{ER} \alpha$-positive cell lines $[13,15,21]$. We confirmed this result in the present study using BYL719 and showed that it was able to disrupt ER $\alpha / P I 3 K$ interactions in MCF-7 cells. We found that BYL719 efficacy on downstream signaling pathways was restricted to PDX mutated for PIK $3 C A$ as described by Fritsch et al. [29]. Our present work reveals that conversely to the results obtained in cells, BYL719 had no significant effect in vivo on ER $\alpha / \mathrm{PI} 3 \mathrm{~K}$ interactions in $\mathrm{ER} \alpha+$ PDX models tested. However, we do not believe that this effect was attributable to in vivo versus in vitro experimental settings (PDX versus cells) as in two ER $\alpha$-negative models $(\mathrm{HBCx}-17$ and HBCx-66), we clearly observed a significant decrease in $E R \alpha / P I 3 K$ interaction upon BYL719 treatment. We can hypothesize that the lack of efficacy could vary according to the breast cancer subtype. Indeed, MCF-7 cells correspond to the luminal A subtype. Unfortunately, all ER $\alpha$-positive PDX models used herein were of a luminal B subtype. This type of cancer may be refractory to the PI3K inhibitor, or at least to its effect at dissociating the ER $\alpha / P I 3 K$ interaction. These results suggest that it would be of interest to find novel molecules able to destabilize this interaction. As a proof of concept, Aurrichio's team showed that a peptide targeting the site of interaction between $E R \alpha / \operatorname{Src}$ was able to disrupt the $\mathrm{ER} \alpha / \mathrm{Src} / \mathrm{PI} 3 \mathrm{~K}$ complex formation, as well as cell proliferation in vitro and in vivo [30]. We also found 
a

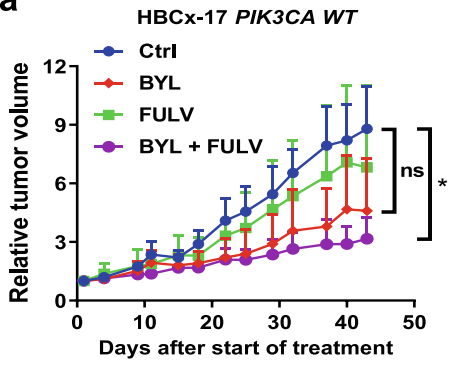

d

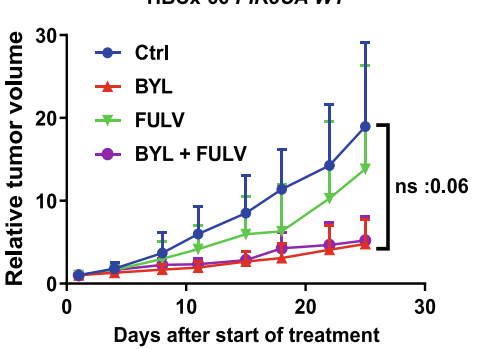

g

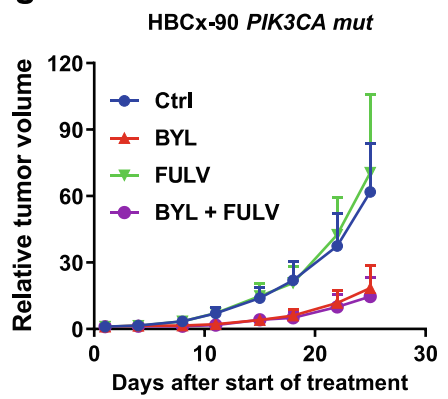

HBC -17

b

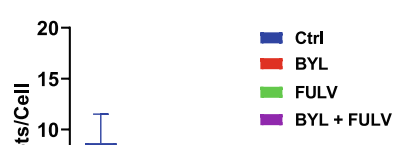

C
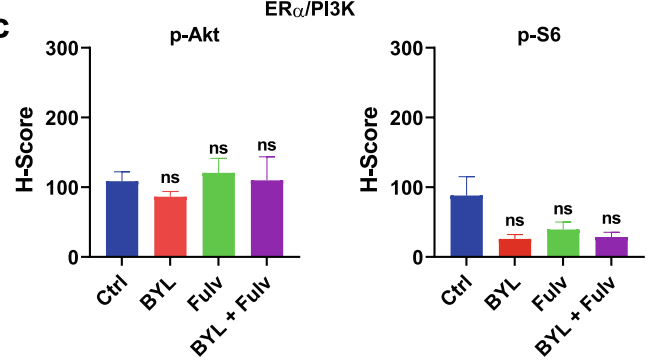

e

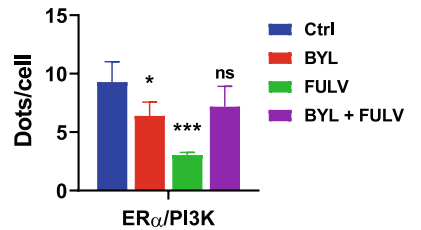

f
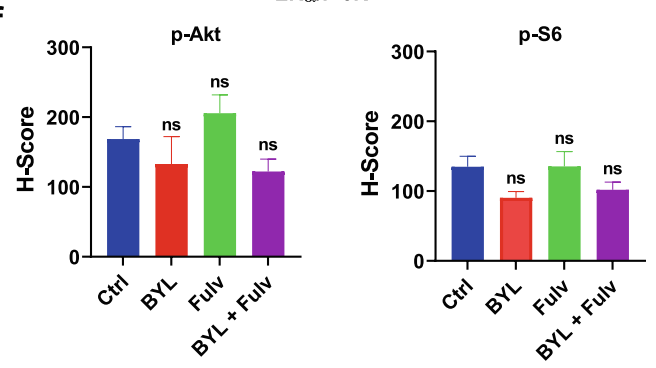

h

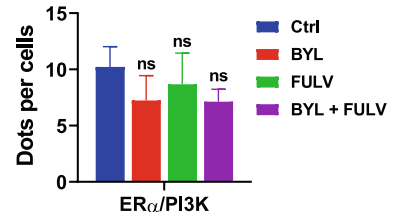

i

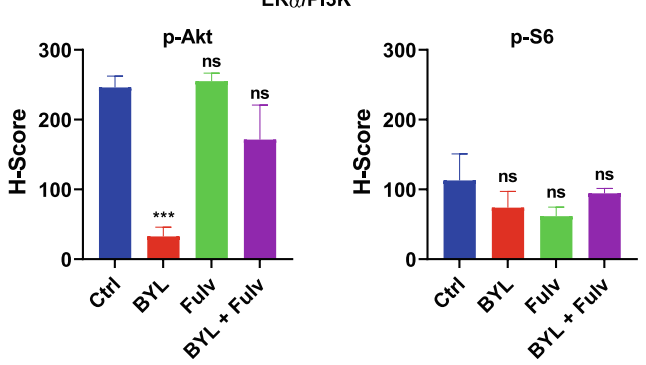

Fig. 6 In vivo drug response to fulvestrant, BYL719 alone, and combined in 3 ERa-negative models. a Effect of the different treatments on $\mathrm{HBC} \times 27$ tumor growth. Each treatment included 10 mice; the $y$-axis indicates the mean of RTV + SD. $\mathbf{b}$ PLA was performed and analyzed as in Fig. 2. c IHC staining was performed on formalin-fixed paraffin-embedded PDX tumors using anti-P-S6 riboprotein (S235/6) antibody. $\mathbf{d}$ Effect of the different treatments on HBCX-801 tumor growth. Each treatment included 10 mice; the $y$-axis indicates the mean of RTV + SD. e PLA was performed and analyzed as in Fig. 2. f $\| \mathrm{HC}$ staining was performed on formalin-fixed paraffin-embedded PDX tumors using anti-P-AKT (S473) and anti-P-S6 riboprotein (S235/6) antibodies. $\mathbf{g}$ Effect of the different treatments on HBCx-90 tumor growth. Each treatment included 10 mice; the $y$ axis indicates the mean of RTV + SD. $\mathbf{h}$ PLA was performed and analyzed as in Fig. 2. i $1 H C$ staining was performed on fixed PDX tumors using anti-P-AKT (S473) and anti-P-S6 riboprotein (S235/6) antibodies. Quantification of highly, medium, and negative cells was performed as described in the "Materials and methods" section. Significance ( $P$ value) between treatments and controls were performed using the $t$ test. ns: not significant 
that this peptide is able to restore tamoxifen sensitivity in a model of MCF-7 cells resistant to tamoxifen [22].

In summary, of the 6 PDX of $\mathrm{ER} \alpha+\mathrm{BCs}$ tested, $\mathrm{HBCx}$ 34, $\mathrm{HBCx}-86, \mathrm{HBCx}-3$, and $\mathrm{BC} 1111$ responded to the combination of BYL719+ fulvestrant, and $\mathrm{HBCx}-86$, $\mathrm{HBCx}-3$, and $\mathrm{BC} 1111$ were PIK3CA mutated. Activation of the non-genomic ER $\alpha$ pathway decreased in treated tumors of 3 PDXs, due largely to fulvestrant and was not always associated with the in vivo response $(\mathrm{HBCx}-3)$. The combination of BYL719 and fulvestrant was more efficient than fulvestrant alone in 3 models; however, this effect was not associated with decreased levels of $E R \alpha / P I 3 K$ complex in xenografts treated with the combination compared to fulvestrant-treated xenografts. Similarly, PI3K-dependent regulation of ER $\alpha$ transcription was observed only in 3 PDXs and was not correlated to PIK3CA mutations nor to the response to the PI3K inhibitor. However, in order to obtain a strong tumor response to combined therapy, it is necessary to simultaneously inhibit genomic and non-genomic signaling. Indeed, complete responses were obtained in $\mathrm{HBCx}-$ 34 xenografts, where both pathways were inhibited. However, when only one pathway was inhibited, the response was partial, as evidenced for $\mathrm{HBCx} 3$ and HBCx86, in which only the non-genomic pathway was inhibited by fulvestrant, whereas for $\mathrm{HBCx}-22$ TamR and BC1111 models, only the genomic pathway was inhibited. For the HBCx-91 model, the response was partial and both estrogen signaling pathways remained unresponsive to fulvestrant, probably due to a very low level of ER $\alpha$. Interestingly, in the 3 models resistant to fulvestrant, ER $\alpha / \mathrm{PI} 3 \mathrm{~K}$ was not disrupted. Inversely, in 2 cases, their interaction increased, although ER $\alpha$ was efficiently degraded in the nucleus and ERG expression was downregulated. This is in accordance with recent results from our lab showing that ER $\alpha / \mathrm{PI} 3 \mathrm{~K}$ interaction increases upon resistance to endocrine therapy [22]. This could be due to a stabilization of ER $\alpha$ by PI3K enzymatic activity. Indeed, PI3K is able to phosphorylate ER $\alpha$ on Serine 167 [31], phosphorylation is involved in ER $\alpha$ degradation, and PI3K inhibitors have been shown to increase its degradation [32]. Unlike previous findings [12], we observed no increase in ER $\alpha$ expression at the mRNA or the protein levels in all ER $\alpha$-positive models treated with BYL719, likely due to the different models investigated (in cellulo vs in vivo).

Concerning ER $\alpha$-negative models, in $\mathrm{HBCx}-17$ and HBCx-66 tumors, fulvestrant had a modest effect on growth inhibition. Interestingly, in these models, fulvestrant alone was able to decrease PI3K pathway signaling probably by disrupting $E R \alpha / P I 3 K$ interactions which might affect PI3K activity and thus downstream signaling. Conversely, in the $\mathrm{HBCx}-90$ model, where fulvestrant had no effect on tumor growth, neither ER $\alpha$ / PI3K interaction nor the downstream pathway was inhibited.

Altogether, our results confirm that the ER $\alpha / \mathrm{PI} 3 \mathrm{~K}$ interaction could be evaluated before associating endocrine therapy with PI3K inhibitors in BC. Moreover, targeting this interaction may improve the response to endocrine therapy in ER $\alpha$-positive tumors and patient survival in ER $\alpha$-negative BCs.

\section{Conclusions}

In summary, the present study identifies ER $\alpha / \mathrm{PI} 3 \mathrm{~K}$ interaction, a hallmark of estrogen non-genomic signaling, as a new potential biomarker associated with a decrease in $\mathrm{BC}$ patient survival. In addition, targeting this interaction may circumvent resistance to endocrine therapies in ER $\alpha$-positive tumors and could contribute to decreasing tumor growth in ER $\alpha$-negative tumors.

\section{Supplementary Information}

The online version contains supplementary material available at https://doi. org/10.1186/s13058-021-01433-8.

\section{Additional file 1: Supplementary methods \\ Additional file 2: Table S1. Baseline characteristics for the patients included in the TMA study. \\ Additional file 3: Table S2. Characteristics of the PDX models. \\ Additional file 4: Figure S1. Effect of PI3kinase inhibitors on ERa/PI3K dimer formation. A. Oestrogen-deprived MCF-7 cells treated or not with PI3K inhibitors LY294002, BYL219, GDC-0032 and GDC-0941 (5 $\mu \mathrm{M}) 15$ min before E2 treatment were incubated with E2 (10-8 M) for 5 min (see Additional supplementary methods). After fixation, in situ PLA for ERa/ PI3K was performed. The detected dimers are represented by red dots. The nuclei were counterstained with DAPI (blue) (Obj:X63). B. Quantifica- tion of the number of dots per cell was performed using image J soft- ware and an automated analysis (see Additional supplementary methods). $P$ value: ${ }^{* * *}<0.01,{ }^{* * *}<0.001$.}

Additional file 5: Figure S2. IHC staining was performed on formalinfixed paraffin-embedded BC1111 PDX tumor using anti-PTEN antibody.

Additional file 6: Figure S3. Proximity ligation assay ( $P L A$ ) was performed on treated $\mathrm{HBC}$-34 tumors embedded in paraffin to study the interactions between ERa and PI3K. IHC staining was performed on the same tumors using anti-ERa, P-AKT (S473) and anti-P-S6 riboprotein (S235/6) antibodies.

Additional file 7: Figure S4. Proximity ligation assay (PLA) was performed on treated $\mathrm{HBC}$-3 tumours embedded in paraffin to study the interactions between ERa and PI3K. IHC staining was performed on the same PDX tumours using anti-ERa, P-AKT (S473) and anti-P-S6 riboprotein (\$235/6) antibodies.

Additional file 8: Figure S5. Proximity ligation assay (PLA) was performed on treated $\mathrm{HBCx}-86$ tumours embedded in paraffin to study the interactions between ERa and PI3K. IHC staining was performed on the same PDX tumours using anti-ERa, P-AKT (S473) and anti-P-S6 riboprotein (S235/6) antibodies.

Additional file 9: Figure S6. Proximity ligation assay (PLA) was performed on treated $\mathrm{HBC}$-22 TamR tumours embedded in paraffin to study the interactions between ERa and PI3K. IHC staining was performed on the same PDX tumours using anti-ERa, P-AKT (S473) and anti-P-S6 riboprotein (S235/6) antibodies.

Additional file 10: Figure S7. Proximity ligation assay (PLA) was performed on treated $\mathrm{BC} 1111$ tumors embedded in paraffin to study the 
interactions between ERa and PI3K. IHC staining was performed on the same PDX tumors using anti-ERa, P-AKT (S473) and anti-P-S6 riboprotein (S235/6) antibodies.

Additional file 11: Figure S8. Proximity ligation assay (PLA) was performed on treated $\mathrm{HBC}-91$ tumours embedded in paraffin to study the interactions between ERa and PI3K. IHC staining was performed on the same PDX tumours using anti-ERa, P-AKT (S473) and anti-P-S6 riboprotein (\$235/6) antibodies.

Additional file 12: Figure S9. A. Proximity ligation assay (PLA) was performed on treated $\mathrm{HBCx}-17$ tumours embedded in paraffin to study the interactions between ERa and PI3K. B. IHC staining was performed on the same PDX tumours using anti-ERa, P-AKT (S473) and anti-P-S6 riboprotein (\$235/6) antibodies.

Additional file 13: Figure S10. A. Proximity ligation assay (PLA) was performed on treated $\mathrm{HBC}$ - 66 tumours embedded in paraffin to study the interactions between ERa and PI3K. B. IHC staining was performed on the same PDX tumours using anti-ERa, P-AKT (S473) and anti-P-S6 riboprotein (\$235/6) antibodies.

Additional file 14: Figure S11. A. Proximity ligation assay (PLA) was performed on treated $\mathrm{HBC}$ - 90 tumours embedded in paraffin to study the interactions between ERa and PI3K. B. IHC staining was performed on the same PDX tumours using anti-ERa, P-AKT (S473) and anti-P-S6 riboprotein (\$235/6) antibodies.

Additional file 15. Reference list.

\section{Acknowledgements}

We would like to thank B. Manship for proofreading the manuscript. We also thank Amelie Colombe, Laetitia Odeyer, and Nicolas Gadot for the technical help.

\section{Authors' contributions}

MLR and EM designed the experiments and wrote the manuscript. JJ and CP performed the experiments and the analyses. LK performed the statistical analyses. OT and IT participated in the discussion of the results and the writing of the manuscript. AD, LDP, EM, LS, and LM established the PDX models and performed the in vivo experiments. REB, SV, and IB performed the RNA extractions and RT-PCR experiments. SCJ embedded the tumor tissues in paraffin blocks and generated the tissue slides for $\mathrm{IHC}$ staining. All authors reviewed and approved the final draft of the manuscript.

\section{Funding}

We thank the Fondation Arc Cancer, Fondation de France, INCA, and DGOS for the financial support of the project and Fondation Arc Cancer and DGOS for JJ's wages.

\section{Availability of data and materials}

All data in our study are available upon request.

\section{Declarations}

\section{Ethics approval and consent to participate}

Before PDX establishment, all patients had previously given their verbal informed consent for experimental research on residual tumor tissue available after histopathological analyses.

PDX establishment was performed after the approval of the ethics committee of the Institut Curie.

Written informed consent was obtained from each patient. The study protocol was approved by the institutional ethics committee.

\section{Consent for publication}

All authors gave consent for the publication of the manuscript in Breast Cancer Research.

\section{Competing interests}

The authors declare that they have no competing interests.

\section{Author details}

'Université de Lyon, F-69000 Lyon, France. ${ }^{2}$ Inserm U1052, Centre de Recherche en Cancérologie de Lyon, F-69000 Lyon, France. ${ }^{3}$ CNRS UMR5286,
Centre de Recherche en Cancérologie de Lyon, F-69000 Lyon, France. ${ }^{4}$ Clinical Oncology Department, Faculty of Medicine, Cairo University, Cairo, Egypt. ${ }^{5}$ Translational Research Department, Institut Curie, PSL University, 75005 Paris, France. 'École Nationale Vétérinaire d'Alfort, BioPôle Alfort, 94704 Maisons-Alfort Cedex, France. ${ }^{7}$ Genetics Department, Institut Curie, Paris, France. ${ }^{8}$ Pathology Department, Centre Léon Bérard, F-69000 Lyon, France. ${ }^{9}$ Medical Oncology Department, Centre Léon Bérard, F-69000 Lyon, France.

${ }^{10}$ Centre de Recherche en Cancérologie de Lyon, INSERM 1052, CNRS 5286, Centre Léon Bérard, Bâtiment D, 28 rue Laennec, 69373 Lyon Cedex 08, France.

Received: 5 October 2020 Accepted: 26 April 2021

Published online: 21 May 2021

\section{References}

1. Ferlay J, Soerjomataram I, Dikshit R, Eser S, Mathers C, Rebelo M, et al. Cancer incidence and mortality worldwide: sources, methods and major patterns in GLOBOCAN 2012. Int J Cancer. 2015;136:E359-86. https://doi. org/10.1002/ijc.29210.

2. Santen RJ, Boyd NF, Chlebowski RT, Cummings S, Cuzick J, Dowsett M, et al. Critical assessment of new risk factors for breast cancer: considerations for development of an improved risk prediction model. Endocr Relat Cancer. 2007;14:169-87. https://doi.org/10.1677/ERC-06-0045.

3. Musgrove EA, Sutherland RL. Biological determinants of endocrine resistance in breast cancer. Nat Rev Cancer. 2009;9:631-43. https://doi.org/1 $0.1038 /$ nrc2713.

4. Ring A, Dowsett M. Mechanisms of tamoxifen resistance. Endocr Relat Cancer. 2004;11:643-58. https://doi.org/10.1677/erc.1.00776.

5. Zhang XH, Giuliano M, Trivedi MV, Schiff R, Osborne CK. Metastasis dormancy in estrogen receptor-positive breast cancer. Clin Cancer Res. 2013;19:6389-97. https://doi.org/10.1158/1078-0432.CCR-13-0838.

6. Isakoff SJ, Engelman JA, Irie HY, Luo J, Brachmann SM, Pearline RV, et al. Breast cancer-associated PIK3CA mutations are oncogenic in mammary epithelial cells. Cancer Res. 2005;65:10992-1000. https://doi.org/10.1158/ 0008-5472.CAN-05-2612.

7. Samuels $Y$, Velculescu VE. Oncogenic mutations of PIK3CA in human cancers. Cell Cycle. 2004;3:1221-4. https://doi.org/10.4161/cc.3.10.11 64.

8. Miller TW, Hennessy BT, Gonzalez-Angulo AM, Fox EM, Mills GB, Chen H, Higham C, Garcia-Echeverria C, Shyr Y, Arteaga CL (2010) Hyperactivation of phosphatidylinositol-3 kinase promotes escape from hormone dependence in estrogen receptor-positive human breast cancer. J Clin Invest 120: 24062413.https://doi.org/10.1172/JCl41680

9. Miller TW, Balko JM, Fox EM, Ghazoui Z, Dunbier A, Anderson H, et al. ERadependent E2F transcription can mediate resistance to estrogen deprivation in human breast cancer. Cancer Discov. 2011;1:338-51. https://doi.org/10.11 58/2159-8290.CD-11-0101.

10. Andre F, Ciruelos E, Rubovszky G, Campone M, Loibl S, Rugo HS, et al. Alpelisib for PIK3CA-mutated, hormone receptor-positive advanced breast cancer. N Engl J Med. 2019;380:1929-40. https://doi.org/10.1056/NEJMoa1 813904.

11. Sarbassov DD, Guertin DA, Ali SM, Sabatini DM. Phosphorylation and regulation of Akt/PKB by the rictor-mTOR complex. Science. 2005;307:1098101. https://doi.org/10.1126/science.1106148.

12. Bosch A, Li Z, Bergamaschi A, Ellis H, Toska E, Prat A, et al. PI3K inhibition results in enhanced estrogen receptor function and dependence in hormone receptor-positive breast cancer. Sci Transl Med. 2015;7:283ra51. https://doi.org/10.1126/scitranslmed.aaa4442.

13. Castoria G, Migliaccio A, Bilancio A, Di DM, De FA, Lombardi M, Fiorentino R, Varricchio L, Barone MV, Auricchio F (2001) PI3-kinase in concert with Src promotes the S-phase entry of oestradiol-stimulated MCF-7 cells. EMBO J 20: 6050-66059. https://doi.org/10.1093/emboj/20.21.6050

14. Simoncini T, Hafezi-Moghadam A, Brazil DP, Ley K, Chin WW, Liao JK. Interaction of estrogen receptor with the regulatory subunit of phosphatidylinositol-3-OH kinase. Nature. 2000;407:538-41. https://doi.org/1 $0.1038 / 35035131$.

15. Cabodi S, Moro L, Baj G, Smeriglio M, Di SP, Gippone S, et al. p130Cas interacts with estrogen receptor alpha and modulates non-genomic estrogen signaling in breast cancer cells. J Cell Sci. 2004;117:1603-11. https://doi.org/10.1242/jcs.0102. 
16. Le Romancer M, Poulard C, Cohen P, Sentis S, Renoir JM, Corbo L. Cracking the estrogen receptor's posttranslational code in breast tumors. Endocr Rev. 2011;32:597-622. https://doi.org/10.1210/er.2010-0016.

17. Song RX, Zhang Z, Santen RJ. Estrogen rapid action via protein complex formation involving ERa and Src. Trends Endocrinol Metab. 2005;16:347-53. https://doi.org/10.1016/j.tem.2005.06.010.

18. Le Romancer M, Treilleux I, Leconte N, Robin-Lespinasse Y, Sentis S, Bouchekioua-Bouzaghou K, et al. Regulation of estrogen rapid signaling through arginine methylation by PRMT1. Mol Cell. 2008;31:212-21. https:// doi.org/10.1016/j.molcel.2008.05.025.

19. Le Romancer M, Treilleux I, Bouchekioua-Bouzaghou K, Sentis S, Corbo L. Methylation, a key step for nongenomic estrogen signaling in breast tumors. Steroids. 2010;75:560-4. https://doi.org/10.1016/j.steroids.2010.01. 013.

20. Soderberg O, Gullberg M, Jarvius M, Ridderstrale K, Leuchowius KJ, Jarvius J, et al. Direct observation of individual endogenous protein complexes in situ by proximity ligation. Nat Methods. 2006;3:995-1000. https://doi.org/10.103 8/nmeth947.

21. Poulard C, Treilleux I, Lavergne E, Bouchekioua-Bouzaghou K, Goddard-Leon $\mathrm{S}$, Chabaud $\mathrm{S}$, et al. Activation of rapid estrogen signaling in aggressive human breast cancers. EMBO Mol Med. 2012;4:1200-13. https://doi.org/10.1 002/emmm.201201615.

22. Poulard C, Jacquemetton J, Tredan O, Cohen PA, Vendrell J, Ghayad SE, et al. Estrogen non-genomic signaling is activated in tamoxifenresistant breast cancer. Int J Mol Sci. 2019;20. https://doi.org/10.3390/ ijms20112773.

23. Cottu P, Marangoni E, Assayag F, de CP, Vincent-Salomon A, Guyader C, de PL, Elbaz C, Karboul N, Fontaine JJ, Chateau-Joubert S, Boudou-Rouquette P, Alran S, Dangles-Marie V, Gentien D, Poupon MF, Decaudin D (2012) Modeling of response to endocrine therapy in a panel of human luminal breast cancer xenografts. Breast Cancer Res Treat 133: 595-606. https://doi. org/10.1007/s10549-011-1815-5

24. Marangoni E, Vincent-Salomon A, Auger N, Degeorges A, Assayag F, de CP, de PL, Guyader C, De PG, Judde JG, Rebucci M, Tran-Perennou C, SastreGarau X, Sigal-Zafrani B, Delattre O, Dieras V, Poupon MF (2007) A new model of patient tumor-derived breast cancer xenografts for preclinical assays. Clin Cancer Res 13: 3989-3998. https://doi.org/10.1158/1078-0432. CCR-07-0078

25. Poulard C, Rambaud J, Le RM, Corbo L. Proximity ligation assay to detect and localize the interactions of ERa with PI3-K and Src in breast cancer cells and tumor samples. Methods Mol Biol. 2014;1204:135-43. https://doi.org/1 0.1007/978-1-4939-1346-6_12.

26. Bieche I, Parfait B, Laurendeau I, Girault I, Vidaud M, Lidereau R. Quantification of estrogen receptor $\alpha$ and $\beta$ expression in sporadic breast cancer. Oncogene. 2001;20:8109-15. https://doi.org/10.1038/sj. onc.1204917.

27. Marangoni E, Laurent C, Coussy F, El-Botty R, Chateau-Joubert S, Servely $J$, de PL, Assayag F, Dahmani A, Montaudon E, Nemati F, Fleury J, Vacher S, Gentien D, Rapinat A, Foidart P, Sounni NE, Noel A, Vincent-Salomon A, Lae M, Decaudin D, Roman-Roman S, Bieche I, Piccart M, Reyal F (2018) Capecitabine efficacy is correlated with TYMP and RB1 expression in PDX established from triple-negative breast cancers. Clin Cancer Res 24: 2605-2615. https://doi.org/10.1158/10780432.CCR-17-3490

28. Tozlu S, Girault I, Vacher S, Vendrell J, Andrieu C, Spyratos F, et al. Identification of novel genes that co-cluster with estrogen receptor alpha in breast tumor biopsy specimens, using a large-scale real-time reverse transcription-PCR approach. Endocr Relat Cancer. 2006;13:1109-20. https:// doi.org/10.1677/erc.1.01120.

29. Fritsch C, Huang A, Chatenay-Rivauday C, Schnell C, Reddy A, Liu M, et al. Characterization of the novel and specific PI3Ka inhibitor NVP-BYL719 and development of the patient stratification strategy for clinical trials. Mol Cancer Ther. 2014;13:1117-29. https://doi.org/10.1158/1535-7163.MCT-130865 .

30. Varricchio L, Migliaccio A, Castoria G, Yamaguchi H, De FA, Di DM, et al. Inhibition of estradiol receptor/Src association and cell growth by an estradiol receptor a tyrosine-phosphorylated peptide. Mol Cancer Res. 2007;5:1213-21. https://doi.org/10.1158/1541-7786.MCR-070150 .

31. Campbell RA, Bhat-Nakshatri P, Patel NM, Constantinidou D, Ali S, Nakshatri H. Phosphatidylinositol 3-kinase/AKT-mediated activation of estrogen receptor a: a new model for anti-estrogen resistance. J Biol Chem. 2001;276: 9817-24. https://doi.org/10.1074/jbc.M010840200.

32. Marsaud V, Gougelet A, Maillard S, Renoir JM. Various phosphorylation pathways, depending on agonist and antagonist binding to endogenous estrogen receptor a $(E R a)$, differentially affect ERa extractability, proteasome-mediated stability, and transcriptional activity in human breast cancer cells. Mol Endocrinol. 2003;17:2013-27. https://doi.org/10.1210/me.2 002-0269.

\section{Publisher's Note}

Springer Nature remains neutral with regard to jurisdictional claims in published maps and institutional affiliations.
Ready to submit your research? Choose BMC and benefit from:

- fast, convenient online submission

- thorough peer review by experienced researchers in your field

- rapid publication on acceptance

- support for research data, including large and complex data types

- gold Open Access which fosters wider collaboration and increased citations

- maximum visibility for your research: over $100 \mathrm{M}$ website views per year

At $\mathrm{BMC}$, research is always in progress.

Learn more biomedcentral.com/submissions 